\title{
Fareed Ben-Youssef
}

\author{
University of California, Berkeley
}

\section{DISRUPTED GENRE, DISRUPTED LIVES: ADIEU GARY AND THE POST-9/11 BANLIEUE AS GHOST TOWN}

DOI: $10.19195 / 0860-116 X .38 .6$

The Western genre's iconic hero, Gary Cooper, haunts Nassim Amaouche's 2009 French film, Adieu Gary — sometimes he appears in found footage; other times, his likeness wanders the streets of the banlieue. He first appears though in an un-heroic state (Fig. 1).

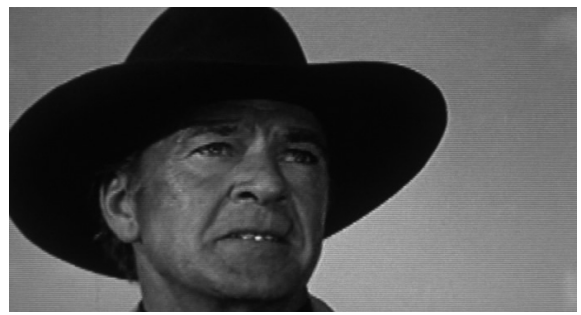

Fig. 1. Gary Cooper on Television. Still taken from Adieu Gary

Pictured in close-up and projected on a blurry television screen, Cooper has a purple bruise on the side of his cheek. The low resolution of the analogue television accentuates the loud Technicolor of the image, so that Cooper's bruise and the red cut on his upper lip gain a disquieting legibility. The film closely crops the cowboy's visage, emphasizing the purplish bruise while downplaying the usual signifiers 
of the cowboy, such as the black hat and his horse. His words prove even more troubling than his beaten and vulnerable appearance. The American hero yells in French, "Tous tuée!" or "All Killed!" His declaration supersedes the ambient noise of the dinner of a French-Arab family near the television. Cooper, then, does not provide any hope for the French-Arab sons and their Caucasian father that struggle in Adieu Gary; instead, he reiterates hopelessness. This moment speaks to a film that reveals the desperate stagnation of a marginalized community and interrogates the heroes of those caught between two clashing cultures.

Belying Cooper's weakened appearance, the low angle framing imbues his figure with a heroic quality that speaks to the positive ideals that the Western hero traditionally represents. Indeed, in interviews, director Nassim Amaouche pinpointed the powerful symbolic dimensions of the iconic Cooper as a counterbalance to the malaise found within his rendition of a disillusioned contemporary France. Amaouche stated that the cowboy myth represents a "flourishing period for America and triumphant capitalism. There are many symbols associated with the figure virility, triumph, and power" (qtd in Chouanière, translation mine). Amaouche elaborates upon a character type analyzed within Robert Warshow's 1954 essay on the Westerner where the author sums up the allure of the gunslinger to be his defense of "the purity of his own image, in fact, his honor" (658). This central, noble autonomy that Warshow argues defines the Western hero, like Cooper, diametrically opposes the subjugated condition of the banlieue inhabitants. Cooper in the film defines the ideals that the marginalized community strives for, as well as the insurmountable distance from ever attaining them. Warshow's essay is crucial for understanding how Adieu Gary plays with the various conventions of the Western.

For the filmmaker, the genre of the cowboy is vital for subversively drawing in his audience. Amaouche admits, "The directors I admire are those that have an elegance to make you believe that they're making a genre film so that it's accessible to a large number of people. But behind it all, there are 20,000 other things going on" (qtd in Croiset, translation mine). He employs a genre perceived as innocuous and purely escapist to disrupt the viewer's preconceptions of the banlieue and its inhabits, offering a personal lens into macro-level geopolitical shifts that followed $9 / 11{ }^{1}$ This

1 To fully understand the daring of Adieu Gary, one must understand the aesthetic and thematic conventions of the banlieue film from which it so forcefully breaks away. Mathieu Kassovitz established and popularized many of the conventions that would define cinematic depictions of the banlieue with his acclaimed 1995 film La Haine. The tale focuses on a racially diverse group of friends in the projects who find a gun and then face terrible consequences. Premiering at the Cannes Film Festival and winning the prestigious Palm d'Or for direction, the production electrified the critical establishment and had "an effect of a bomb" on the French culture in the months after its release (qtd in Vincendeau 81).

The hallmarks of this new cinema are established in the first sequence of Kassovitz's production. Found footage from early 90s race riots in Parisian banlieues, shows a lone citizen challenging a wall of riot police, daring them to shoot. Editing such documentary images of urban chaos against an allegorical one of an Earth that explodes, the film establishes the central volatility of the banlieue. 
essay will show how Adieu Gary refashions the Western aesthetic and its iconic heroes for this post-9/11 context to signify not strength but weakness. Amaouche scouted the film's location in a banlieue that resembled, to him, a Western ghost town (Padellec). This setting dislocates the film from the urban space that defines most films about the banlieue into an empty allegorical one. In its appropriation of the ghost town convention, the film becomes a unique example of a disrupted, transnational Western which visualizes the disrupted lives of banlieue youth, articulating the psychological disempowerment of an ethnic group framed in legal terms as a potentially violent threat.

America, through the ambivalent presence of Cooper, visually subordinates the European setting. Such domination brings to mind America's hold over international law, particularly the creation of global security law that was spearheaded by the United States after 9/11. The attacks set the stage for an immediate transformation of international law led by an American executive dedicated to making global its War on Terror. The Bush administration accomplished this task by harnessing the power it held as a member of the U.N. Security Council to pass UNSC Resolution 1373, which legal scholar Kim Lane Scheppele calls "the boldest resolution it had ever passed," emphasizing the unprecedented requirement of U.N. member states to align their domestic laws with its mandate (253). Its poorly defined key terms, like terrorism, mired U.N. partners in the dangerous muddle of meaning that was emblematic of so much of post-9/11 law, where human rights were supplanted by concerns for increased security (Scheppele 267). Adieu Gary initially appears distant from this transformation in international law. Yet its French-Arab protagonists negotiate mass media envisionings of the "terrorist" in ways that highlight the added pressures the controversial resolution placed upon Arab and racially mixed populations.

Prior to its presentation of the banlieue's main street, where plastic bags stand in for tumbleweeds, the film's opening sequence presents the banlieue as funda-

The film identifies the poor urban neighborhoods as a place where the marginalized clash with a dangerous establishment. Angry, diverse masses suffering overwhelming entrapment define this urban space. This reality, bordering on anarchy, is dangerously alive with a rebellious sentiment ready to violently challenge the oppressors of the French state. The convention of the angry and constricted banlieue codified in La Haine has manifested itself repeatedly in different permutations of the banlieue film, including 2008's Entre les Murs by Laurent Cantet and 2009's Un Prophète by Jacques Audiard.

Director Nassim Amaouche strips the banlieue of its urban setting. Gone is the bustling cityspace of other banlieue films. Gone is their enlivening anger and violent volatility. Premiering at the same edition of the Cannes Film Festival where Un Prophète won the Grand Prix, Amaouche abandoned all the tropes of his film type. He replaced them with the conventions of the Western genre and added a deep, lethargic ambience. Such a rebuke of convention in allegorically merging the Western genre with the banlieue permits the film to articulate with striking nuance the alienation of a mixed generation caught in a rootless limbo between two cultures - a France that will only accept them as marginalized subordinates and the confusing, inaccessible Arab world. The film explores the consequences of this social alienation and how individuals adapt psychologically. 
mentally detached from the greater French society. It accomplishes this through a sequence that showcases the return of the protagonist Samir from prison to his home in the banlieue. Contrasting a Western genre steeped in the sun-drenched bucolic, the first frame is one of pitch black darkness. Aural cues of rustling chains indicate that the blackness represents a prison. After Samir is let outside by the guard, the film cuts to a point of view shot from the passenger side of his brother's car. What surrounds the newly free Samir is not the open French countryside or a lively city, but a dark railroad tunnel, illuminated solely by the vehicle's headlights. Freedom for the mixed-race Arab amounts to nothing more than a further enclosure. The opening of the film where the camera moves toward a white light, the light at the end of a tunnel, functions as a metaphor that links returning to the banlieue as a death in its own right (Fig. 2). Moving toward the center of illumination, the soundtrack signals a shift into an Arab domain. Music by the Palestinian band Trio Jourban who specialize in melodies played with the Oud — or Arab lute — come to dominate the score with an ever louder and complex crescendo ("Le Trio Jourban"). As the whiteness fills the screen, the film finally reaches its afterlife, the banlieue. The title Adieu Gary, which flashes across the screen, features a distinct font colored with a gritty brown and tan color that evokes the dusty color palette of the stone buildings on the Western-style street. The title brings together a French language with an American icon, foreshadowing its odd mélange of cultural iconography. The way in which the film's title translates to "Goodbye Gary" immediately pushes forth the possibility that Cooper might be a fleeting, even an inadequate savior for the troubles facing the banlieue. With an appearance of this title juxtaposed against a solidly white background, the film definitively establishes the banlieue shared by Samir and his family as a metaphoric oblivion belonging to an empty plane that exists outside of quotidian French life.

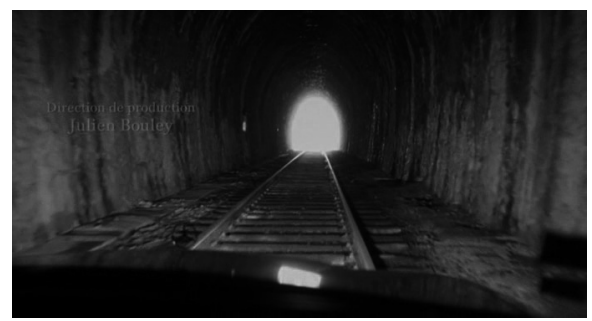

Fig. 2. Returning to the afterlife of the banlieue. Adieu Gary

Warshow writes that the landscape serves a dual function in the Western - it can either accentuate the stature of the hero or cut down his prominence (659). Amaouche films the banlieue street so that it smacks of desolation, sucking any vivacious energy out of its denizens. Walking down the street upon his arrival from prison, the hero 
Samir is confronted by an empty setting that confounds him. A point of view shot unveils what the recently free man finds so unsettling. The camera pans by a building's worn façade. Here, greenery peeking out of the crevices connotes not fertility, but rather the space's dilapidation. When the pan stops, the camera falls on a random fuel dispenser that is seemingly out of place. The presence of the machine unable to provide fuel for locomotion implies the inescapable quality of the banlieue setting. Citizens are left to immobility and must stagnate. The one mode of locomotion that holds court on this lonely road, the "horse" visible in many establishing shots, is the electric wheelchair of the disabled drug dealer Abdel. Pictured slowly moving down the boulevard, the film underscores the unfeasibility of movement for the French-Arab stuck in the banlieue by showing movement at its most halting.

Outside the stifling banlieue setting, prospects for the mixed-race individual are no better. The space, captured without any cinematic Western flourishes that so characterize the banlieue, appears to transform, via their uniforms at the supermarket, Samir and his brother Icham into inhuman stereotypes. In his discursive study, The Threat of Race, theorist David Theo Goldberg writes that contemporary Muslims are "the unwanted, the avoided, Europe's untouchables" (166). In the first shot of a setting outside the desolate banlieue, the film brings to life Goldberg's assessment of the European Muslim. Icham stocks the cheese section of the dairy aisle as an employee wearing a mouse costume (Fig. 3). Only Icham's white father Francis, who wanders into the scene, remarks on the strangeness of his wardrobe, asking with apparent disgust in his voice, "What's this?" His reaction is atypical, as illustrated by the shopper in the background who picks out his cheeses without ever taking a second glance at the strange dehumanizing spectacle. The light jazz flute pumped in through the store's loudspeaker reinforces the normality of a mixedrace citizen-as-vermin walking within the white majority's midst. These two distinct settings represent the only choices available to the Muslim man and the mixed-race individual of the banlieue - an urban space of lethargy or a France that denigrates them. These individuals, caught between two punishing worlds, need a hero someone who faces a broader antagonistic society head-on and who can still thrive. In short, they need Gary Cooper.

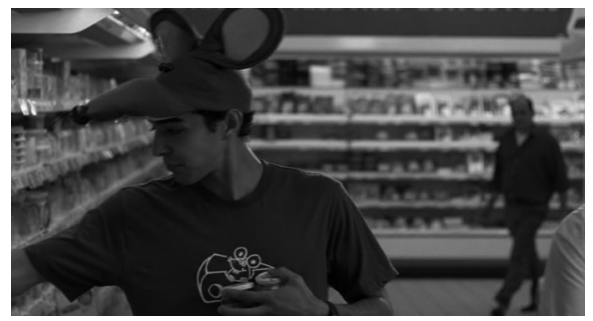

Fig. 3. Icham in a mouse uniform at the supermarket. Adieu Gary 
Adieu Gary's most striking sequence occurs late in the film, where a Gary Cooper lookalike from his role as Marshal Will Kane in High Noon rides on horseback toward the sunset (Fig. 4). Positioned near the camera before making his descent over the rocky terrain, this iteration of Cooper dominates the landscape far below and invokes an undeniable sense of power over the environment. Disrupting the classic iconography, however, is the sound of the Oud. The film lingers on this shot for a few moments, emphasizing that the Western genre, fundamentally a symbol of American power, has been incorporated within a decidedly near-Eastern context, so that the Western lawman becomes a cross cultural icon that represents individual strength. While the presence of Gary Cooper exemplifies this value that the FrenchArab youth so desire, the camera's continued isolation of Samir from his peers and the greater French society illustrates the futility of a hero that speaks to empowered individualism.

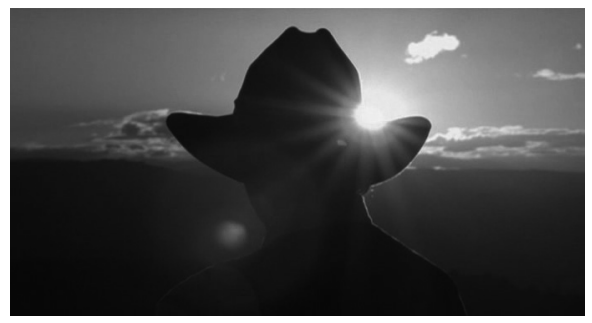

Fig. 4. Gary Cooper comes to the banlieue. Adieu Gary

The film signals that the Western hero Gary Cooper and Samir are analogues for each other. An explicit parallel framing brings these two divergent figures into direct dialogue. After Samir has slept with his beloved Nejma and lies in a naked embrace, the film cuts to a scene where Gary Cooper tells a luxuriating woman to "get dressed" (Fig. 5). Post-coital moments connect the two heroes across time and space. It is worth reiterating that Samir has an emotional bond with his lover that Cooper does not share, a distinction that denotes the film's skeptical view that Cooper embodies a kind of cold American masculinity.
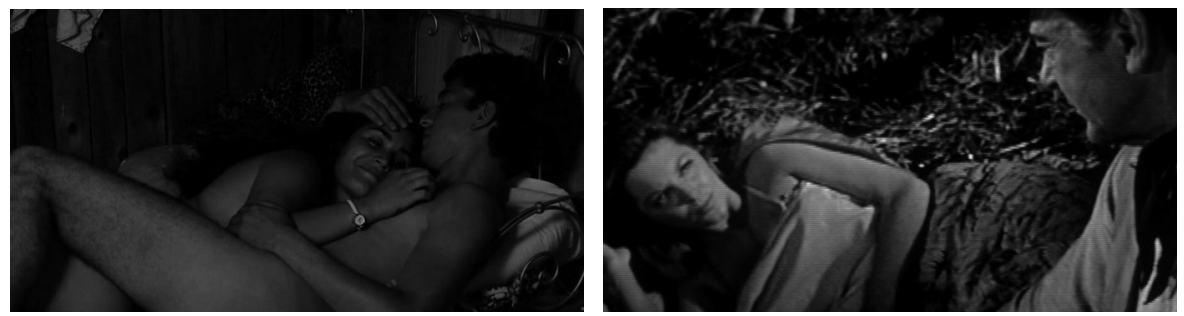

Fig. 5. Samir's post-coital moment juxtaposed Fig. 5 cont. Adieu Gary. against Gary Cooper's. Adieu Gary 
Through the differences in their entrances into the banlieue, the film also sheds light upon the great disparities in their respective power. Cooper gallops down the ghost town's main street. Whereas Samir's arrival into this space was punctuated by long point of view shots designed to evoke the strange aura of the banlieue, the camera captures Cooper's arrival more simply. It pans toward Cooper as he grows ever larger in the frame. Overlaid onto the image of the approaching hero is a triumphant musical score that evokes a classic Western. The cumulative effect of the more simple techniques of enlargement privileges the individual over his environment. The banlieue does not matter, only the Westerner does.

Upon his return from prison for petty drug dealing, Samir is identified as in some ways the antithesis of Cooper. When Samir goes back to his childhood bedroom, the objects inside the space emphasize his alienated condition. Bric-à-brac in the background comments on Samir's perceived societal position (Fig. 6). A dart board sits behind his head: he cannot be the gunfighter, only the target for a world that seeks to consolidate its minorities into simplistic stereotypes. A large watercolor copy of a Native American chief also sits on the wall, positioning Samir as fundamentally opposed to Cooper and his triumphant symbolism. Visually pairing the French-Arab with the Native American proposes that Samir can never fully take on the role of the Western hero because the racial aspect of his identity leaves him doomed, an eternal figure of lack like Goldberg's Muslim or a warrior chief in a Gary Cooper film.

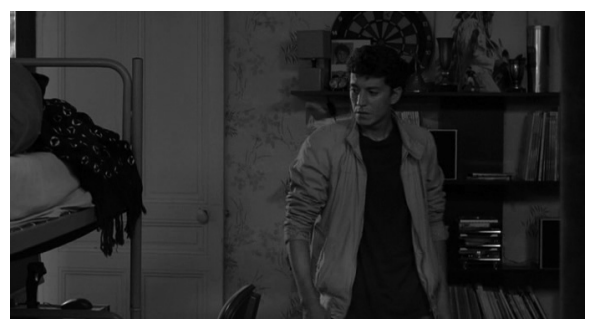

Fig. 6. Dart board and Native American chief poster on shelf behind Samir. Adieu Gary

His position as a displaced colonial subject ensures that Samir's life must be one of theatrics, must be dictated by the parameters of a set role. Goldberg writes that the immigrant in Europe finds himself enmeshed in different, "racially driven economies," including one of labor (183). Here, the immigrant sustains the white majority by taking on jobs the locals refuse. Samir goes to work at the supermarket and is expected to assume the objectified position of the menial laborer, the aforementioned mouse. The system forces him to act out a humiliating bestial perception before a largely Caucasian public. Working at the store, Samir experiences a racist violence that, Goldberg writes, manifests itself in various forms against immigrants. As Samir stands in his break room that features barred windows which recall the 
prison, his name suddenly blares over the store's intercom. He is repeatedly called back to the dairy aisle where he must perform his work in costume. As shown in this sequence, Samir has no autonomy in the economy of labor and experiences the racist violence of being "watched, channeled, documented, obliged, commanded, and pressured" by those controlling the system of power (Goldberg 183). Even outside the prison world, Samir is under the command of a panoptic voice, except the jailer happens to be his white boss.

Warshow writes that the Westerner enacts a performance of his own - that of the gunfight. Even if he has grown disillusioned by the battle, he continues to wage it. What redeems him is that he will "continue to play his role perfectly the pattern is all" (Warshow 662). Yet Samir, the man most directly correlated with the Western hero, suffers precisely because he cannot play the role imposed upon him, thus he cannot be redeemed. As he suffers an emotional breakdown in front of his father, Samir states that he cannot stand being a part of the "carnival" any longer. The staging of the next shot reinforces the reason for his disenchantment (Fig. 7).

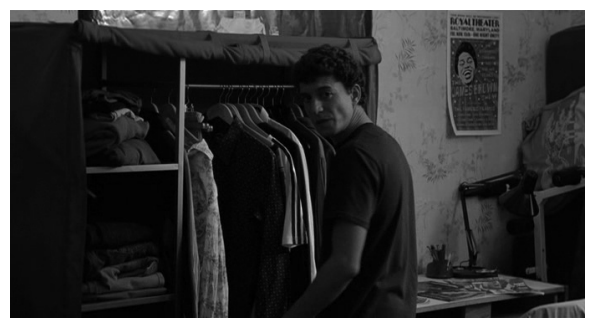

Fig. 7. Samir staged against a poster of Little Richard and a cropped poster of Muhammed Ali. Adieu Gary

To his right in the frame is a poster for a James Brown concert playing at the Royal Theater. A caricatured portrait of the smiling soul singer in the poster indicates that Samir can only hope for a life of performative subjugation to white establishment society. The most telling aspect of the shot is not the poster that is fully visible, but the one that is half cropped out of the frame. Seen earlier, it is an enlargement of the famous photo of Muhammad Ali standing triumphantly over a beaten Sonny Liston. Arms flexed, the fighter dominates the ring just as Gary Cooper dominates the banlieue. The photo, taken less than a year after Ali's conversion to Islam, speaks to the possibility of thriving in a white world with a Muslim identity ("Muhammed Ali vs Sonny Liston"). That the film crops this photo off in the shot of Samir as he laments his exploited condition shows that the path of the boxer is closed to him as well. Warshow states that the Western hero continues to be invincible because he battles on to affirm who he is and can do so because he "must live in a world that permits that statement" (662). The France of 
the film is a world that does not allow the mixed-race individual the opportunity of self-affirmation; therefore, any attempt to fight for oneself is nothing but an exercise in futility, a sure means for further cultural rejection. Adieu Gary goes far beyond exposing the false hope offered by Western pop cultural icons, suggesting that they create a masochistic self-loathing within the psyche of the marginalized. For the mixed-race individual or colonial subject, the destruction of the integrity of his or her own identity comes solely not without, but also within. The earlier linking of the protagonist to a mythic enemy of America's past presages the film's linking of Samir and his brother with the state's modern enemy, the Arab terrorist. In a scene involving videogames, Adieu Gary visualizes how Western pop cultural products create an unsustainable subject position for the marginalized: one where feelings of power are generated through the destruction of demonized representations of the self.

In Black Skin, White Masks, Frantz Fanon indicts the French colonial structure for psychologically destroying the colonized black man. He elucidates upon the impact of European pop culture, namely in "Tarzan stories, the sagas of twelveyear-old explorers, the adventures of Mickey Mouse, and all those comic books" (146). Fanon argues that these carry a perverse dimension in which the racially marginalized existing on the periphery of empire are placed in an untenable situation psychologically and linguistically. Adieu Gary brings a parallel phenomenon into a post-9/11 context by showing the banlieue inhabitants playing video games and relishing the killing of Arab terrorists. While the Arab's pop cultural annihilation distances the racially mixed individual from his Near-Eastern roots, the film's presentation of its exhilaration plays out the process Fanon describes in a more ambivalent, fully articulated way.

Besides Gary Cooper, a military video game SOCOM: U.S. Navy SEALs is the sole pop cultural object that ever takes hold of the film's attention, filling the screen entirely (Fig. 8). The shooter is a mediation of the wars that stemmed from the War on Terror. The video game seems ferociously alive as the game's camera weaves and bobs with the action. The general presentation is entirely unlike the slow moving, steady camera of the main film. The players, Samir's brother Icham and the disabled drug dealer Abdel, seem emboldened and energized. The terrorist enemy is a pixelated and distant mass wearing a white turban. Once he falls into the players' crosshair, he is flung back dead onto the desert floor. Cutting away from the virtual world, the film shows these two players sitting rigid and unblinking. As they take the perspective of American soldiers, they concentrate on the virtual environment with far more attention than they do their own material one. Without a second thought, these sons of immigrants bandy about slurs, calling the fighters interchangeably terrorists and Arabs. 


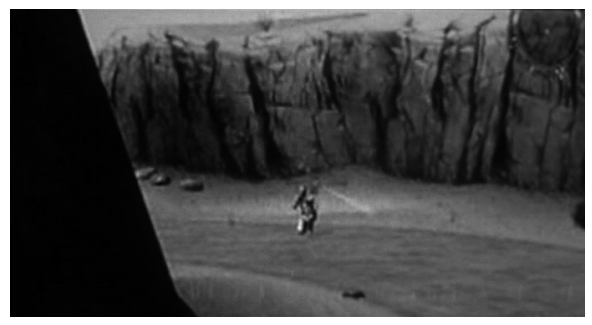

Fig. 8. Facing an Arab terrorist in a military video game. Adieu Gary

The scene of gleeful abandon in the digitized battlefield upholds Fanon's thesis of collective catharsis, as experienced by the formal colonial subject. The framework of the video game allows players of Arab descent to "subjectively adopt a white man's attitude" (Fanon 147). A video game, then, permits the player to become the bearer of the white gaze at its most racist and violent, through the reticule of a rifle aiming to kill the blurred and aggressive vision of the Other. The player fights a vision of the Muslim that represents violent death, what Goldberg calls Europe's nightmare (Goldberg 165). Icham expresses the sheer pleasure of such an act when he brags about his video game exploits at the dinner table. Is his pleasurable adoption of the dominant colonial perspective, in Fanon's terms, an act "permeated with sadism?" (147). On one level, Icham derives joy by shooting a representation of himself; ${ }^{2}$ and yet, the film encourages us to wonder what strength this vision of power offers the marginalized subject otherwise trapped in an economic, social, and psychic limbo? Icham's family points out the irony that he is destroying Arabs onscreen, and yet, Icham's nonchalance about this fact suggests this facet of the game is not what compels him. Sitting at the head of the table and in the frame's center during his reminiscences of the videogame, the film suggests paradoxically that the transporting video game "centers" him. The peripheral figure, armed with a digital rifle, might for an instant at least be brought out of the edges in his own mind. Adieu Gary complicates Fanon's formulation, showing that such visions might not simply lead to a destruction of self but that they might allow for a simultaneous and rare reassertion of self, unsustainable though it might be and necessitating the adoption of a destructive gaze.

2 The sequence of estranging delight and the film as a whole, infatuated by and alienated from visions of Gary Cooper, provokes reflection on a phrase offered by James Baldwin in his 1965 essay "The American Dream and the American Negro." He writes, "In the case of the American Negro, from the moment you are born every stick and stone, every face, is white. Since you have not yet seen a mirror, you suppose you are, too. It comes as a great shock around the age of 5, 6, or 7 to discover that the flag to which you have pledged allegiance, along with everybody else, has not pledged allegiance to you. It comes as a great shock to see Gary Cooper killing off the Indians, and although you are rooting for Gary Cooper, that the Indians are you" (Baldwin; emphasis mine). 
Such a mode of fraught catharsis for the mixed-race individual transforms the Arab world into an ever more distant reality. Icham considers moving to North Africa because it "will be where I feel more at home." His white father Francis considers this to be nothing more than idle fantasy and remarks on his son's struggle to learn Arabic. Reinforcing the boy's alienation from the Arab world, after his round of video gaming, the film presents a scene of Icham listening to Arabic cassettes. Whereas he was all smiles at the thought of smoking out the Arab enemy, listening to the extended Arabic dialogue leaves him visibly anxious. A long take makes clear that the prolonged immersion, rather than a momentary flirtation with the language, is supremely aggravating. Icham begins to fidget in his seat as the recording plays. His eyebrows rise in confusion before he quickly stops the cassette. Once he does so and the Arab language has been cut off from the scene, he breathes a sigh of relief. His pop culture has rendered the Arab world into a confusing cacophony. His immersive video games that provide the semblance of power only further root him in limbo.

While the condition of the immigrant in Europe is indeed desperate, Goldberg makes a special point to highlight the even more devastating experience of the mixedrace individual who is a mélange of the North African and the local working class. These people, like Icham and Samir in Adieu Gary, suffer the "non-acceptance of non-acceptance, of discrimination, and perpetuated exclusions" (Goldberg 184). The homeland of their parents is no longer theirs and they cannot claim Europe as their own. The film suggests engaging in the fantasy for a better life or an empowered condition is wasteful. The white Maria tells her racially mixed son José still dreaming of the return of his father, "stop watching these [Gary Cooper] movies — there's no point!" Adieu Gary underlines the unfeasibility of real or imagined power, and ultimately establishes the impossibility of productive multiculturalism in contemporary France.

Fantasy is defined as a pointless indulgence - a point best articulated in the brief scene where a young banlieue inhabitant takes on the oncoming state-owned Société Nationale des Chemins de Fer français (SNCF) train (Fig. 9). During a moment where the soundtrack blares with the sounds of Trio Jourdan's music, this brown-skinned man steps onto the railroad tracks with his red shirt in hand and proceeds to act the part of a toreador. Caught in a wide shot, he swaggers his hips with theatrical flair. The speeding train acts as the bull and a symbol for a French state made bestial. For a fleeting moment, the authority is objectified by an outsider from the banlieue. Following a shot of the distant train, the film shows the toreador's grave face in close-up. He embodies confidence and shows the same fearlessness of a Westerner. Yet he cannot overcome his foe. The last image of their duel does not show the toreador sidestepping the roaring mechanical beast, but rather a shot of the unstoppable train. Its SNCF logo, the mark of the state, is clearly visible. The scene illustrates that the dream of the Arab toreador slaying the French bull cannot be maintained. For the denizens of the banlieue, a denigrated French establishment that they can control is but a fragile illusion that can be easily broken. 


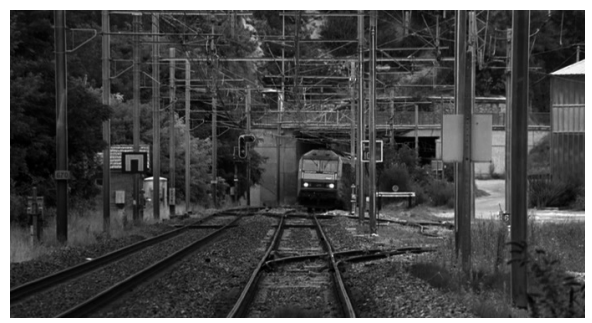

Fig. 9. Banlieue inhabitant takes on the SCNF train as a toreador. Adieu Gary

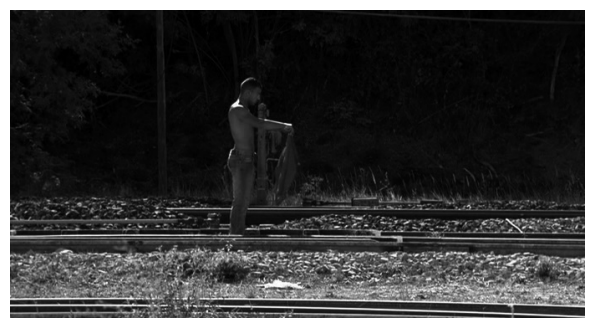

Fig. 9 cont. Adieu Gary

For a brief moment near the close of the film, the banlieue seems to spring to life allowing a break from the deadening condition of its status quo. Samir and Icham's father Francis, an out-of-work factory laborer, finally repairs a broken piece of industrial equipment that has long fixated his attention. Once he completes the task with Samir's assistance, the machine begins to hum. The sound emanating from the machine resembles a heartbeat. Its rumbling pulse feeds into the town and brings its inhabitants out of their stupor. Two former factory workers, a white Frenchman and an Arab immigrant, proceed to share their awe before the machine. For a few moments, racial boundaries break down and the idea of industrial progress connects distant ethnic groups. Suddenly, the machine breaks down again and the community returns to its former fractured state. The distant call of the church bells clash with the sounds of the Oud. The bells fade away and the screen suddenly fills with the image of an old Arab immigrant readying himself for prayer, while whispering "praise God" in Arabic. He then proceeds to walk with Icham to the mosque. The union's former hub, the "Maison du Peuple," has been reconstituted into a site of Muslim worship. Ending on a shot of the mosque that has replaced the racially inclusive Union, the film closes on a somber note. The arc of Icham's character suggests that the mixed French-Arabs of the banlieue will choose the facet of their identity that places them in a broader community, even if the Muslim group is shunned from mainstream society. Conservative Islam thus becomes the sole route for an autonomous identity; however, the film's ambivalence reveals how this embrace of Islam 
further condemns the French-Arab subject to a life in limbo, trapped in an existential ghost town somewhere between life and death.

In a 30 second shot of Samir taking a coffee break outside the supermarket where he works, the film visually frames the mixed Arab individual as a phantom in French culture (Fig. 10). This potent image speaks to just how marginalized individuals like Samir are within a France that claims to be the standard bearer for equality, fraternity, and liberty. He stands with a black colleague who wears the costume of an angel, a detail in the mise-en-scène that lends the scene the aura of the afterlife. They lean on blue and red crates which, when taken with the woman's white costume, form the tricolor of France's flag; hence, the film compositionally demarcates the moment as one of explicit social commentary. At the lower edge of the frame lies a puddle that reflects the workers. Where the woman has a complete reflection, the gray silhouette of Samir appears fractured, like a ghost. He is pushed toward a metaphorical death by a culture that has no need for individuals who challenge racial binaries. Samir exists outside the tricolor ideal, thrust into a state of inequality, ostracization, and incarceration. His alienation highlights the corrosive nature of France's official and unofficial stance toward its immigrant population.

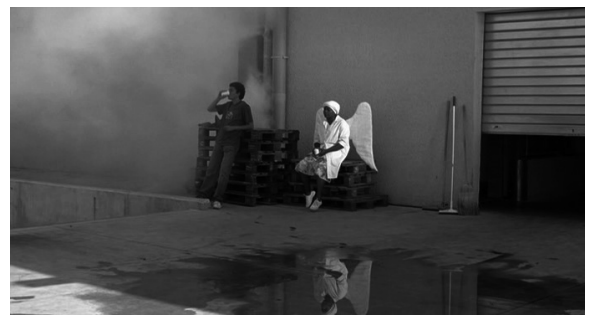

Fig. 10. Samir takes a coffee break with a black colleague, with an angel. Adieu Gary

Returning to the beaten Gary Cooper who declares that all have been killed, the film can be seen as a eulogy for a broad swath of France imprisoned in the banlieue. The person delivering the stark words is a Western hero that continues to have a hold not just on national consciousness, but on a global one, holding sway over both marginalized citizens and policy makers like President Bush. Adieu Gary employs a disrupted genre variant, to show us the possibility as well as the trap of the Gary Cooper icon and the Western as an apt expression of the French-Arab's vexed subject position in the ghost towns of post-9/11 France - one where the route to exhilaration is tinged with kind self-destruction, where a feeling of belonging is suffused with isolation, and the fascinating ambivalence offered by a hybridized condition between cultures must be effaced, must be all killed. 


\title{
WORKS CITED
}

Adieu Gary. Dir. Nassim Amaouche. Perfs. Jean-Pierre Bacri, Yasmine Belmadi, Mhamed Arezki, Sabrina Ouazani. Studio Canal, 2009. Digital Copy.

Baldwin, James. "The American Dream and the American Negro." The New York Times (7 March 1965). Web. 1 Nov 2015. https://www.nytimes.com/books/98/03/29/specials/baldwin-dream. html.

Chouanière, Thomas. "Interview de Jean-Pierre Bacri et Nassim Amaouche.” EVENE.fr. May 2009. Web. 1 Nov 2010. http://www.evene.fr/cinema/actualite/interview-bacri-amaouche-adieu-garycannes-2030.php? $\mathrm{p}=2$.

Croiset, Laure. "L'interview de Jean-Pierre Bacri et Nassim Amaouche." Toutlecine.com. HiMedia Publishing Network. 25 May 2009. Web. 1 Nov 2009. http://www.toutlecine.com/film/ interviews/0038/00385107-adieu-gary.html.

Entre Les Murs. Dir. Laurent Cantet. Perf. Francois Begaudeau. Sony Pictures, 2008. DVD. Sony Pictures, 2009.

La Haine. Dir. Mathieu Kassovitz. Perfs. Vincent Cassel, Saïd Taghmaoui, Hubert Koundé. Studio Canal, 1995. DVD. The Criterion Collection, 2010.

Fanon, Frantz. Black Skin, White Masks. Trans. Charles Lam Markmann. New York: Grove Weidenfeld, 1968. Print.

Goldberg, David Theo. The Threat of Race. Reflections on Racial Neoliberalism. Oxford: WileyBlackwell, 2009. Print.

“Le Trio Jourban.” letriojoubran.com. Zamora Productions. 2010. Web. 31 Oct 2010. http://www. letriojoubran.com/en.

Padellec, Emilie. "Portrait: Nassim Amaouche." nisimasa.fr. 18 May 2009. Web. 1 Nov 2010. http:// www.nisimazine.eu/Amaouche-Nassim.html.

Un Prophete. Dir. Jacques Audiard. Perf. Tahar Rahim. Sony Pictures, 2009. DVD. Sony Pictures, 2010.

Scheppele, Kim Lane. "The Empire of Security and the Security of Empire." Temple International \& Comparative Law Journal 27 (2013): 241-278. Print.

Vincendeau, Ginette. La Haine. Chicago: University of Illinois Press, 2005. Print.

Warshow, Robert [1954]. "Movie Chronicle: The Westerner." Film Theory and Criticism. Ed. Leo Braudy and Marshall Cohen. New York: Oxford University Press, 1992. Print.

\section{DISRUPTED GENRE, DISRUPTED LIVES: ADIEU GARY AND THE POST-9/11 BANLIEUE AS GHOST TOWN}

\author{
Summary
}

The War on Terror was made global in 2001 through U.N. Resolution 1373. Nassim Amaouche's 2009 Adieu Gary appears distant from this transformation in international law. Yet its French-Arab protagonists negotiate mass media envisionings of the "terrorist" in ways that highlight the pressures the controversial resolution placed upon Arab and racially mixed populations. Adieu Gary subversively refashions the Western aesthetic and its iconic heroes for this post-9/11 context to signify not strength but weakness. In its appropriation of the ghost town convention, the film thus becomes a unique example of the disrupted, transnational Western which visualizes the disrupted lives of banlieue youth, 
articulating the psychological disempowerment of an ethnic group framed in legal terms as a potentially violent threat.

My paper unveils the richness of this singular film's commentary on French public discourse through an interdisciplinary framework that combines analysis of Resolution 1373's impact in France, an awareness of the film's intertextual gestures to classic Hollywood Westerns, and a post-colonial theoretical perspective. A vision of the terrorist Other, codified in law and propagated in popular culture, affects the French-Arab's self-perception in the film. The sheriff of the Western, emblematized by Gary Cooper's lawman from High Noon who seems to haunt the setting, reinforces the banlieue inhabitant's powerless state. Conservative Islam then becomes the sole route for an autonomous identity; however, the film's ambivalence reveals how this embrace of Islam further condemns the French-Arab subject to a life in limbo, trapped in an existential ghost town somewhere between life and death.

\title{
ROZBITY GATUNEK, ROZBITE ŻYCIE - ADIEU GARY I „POSTJEDENASTOWRZEŚNIOWE” PRZEDMIEŚCIE JAKO WYMAR EE MIASTO
}

\begin{abstract}
Streszczenie
Wojna z terroryzmem stała się globalna w 2001 roku w wyniku rezolucji ONZ nr 1373. Film Nassima Amaouche'a Adieu Gary z 2009 roku wydaje się daleki od tej transformacji w międzynarodowym prawie. Jednakże jego francusko-arabscy protagoniści negocjują massmedialne wyobrażenia „terrorysty” w sposób, który rzuca światło na presję, jaką ta kontrowersyjna rezolucja wywarła na arabskiej i rasowo mieszanej ludności. Adieu Gary subwersywnie przemodelowuje zachodnią estetykę i jej ikonicznych bohaterów funkcjonujących w owym ,postjedenastowrześniowym” kontekście, żeby podkreślić nie siłę, lecz słabość. W swoim przyswojeniu konwencji wymarłego miasta film ten staje się wyjątkowym przykładem rozbitego transnarodowego westernu, który wizualizuje rozbite egzystencje przedmiejskich młodocianych, artykułując psychologiczne pozbawienie autorytetu etnicznej grupy, ujmowanej w prawniczych terminach jako potencjalna groźba przemocy. Mój esej ukazuje bogactwo komentarza filmu na temat francuskiego publicznego dyskursu, komentarza opartego na interdyscyplinarnej podbudowie, który łączy analizę oddziaływania rezolucji 1373 na Francję, świadomość filmowego intertekstualnego nachylenia ku klasycznemu hollywoodzkiemu westernowi i postkolonialną teoretyczną perspektywę. Wizja terrorystycznego INNEGO, skodyfikowana przez prawo i propagowana w popularnej kulturze, oddziałuje na wzajemne postrzeganie się w filmie Francuzów i Arabów. Szeryf z tego westernu, symbolizowany przez człowieka prawa granego przez Gary'ego Coopera z filmu $W$ samo południe, który zdaje się nawiedzać okolicę, wzmacnia tkwiących w bezsilności mieszkańców przedmieścia. Konserwatywny islam staje się więc jedyną drogą autonomicznej jednostki; jednakowoż dwuznaczność filmu odsłania, jak owe kleszcze islamu skazują francusko-arabskich obywateli na życie w otchłani, złapanych w pułapkę egzystencjalnego wymarłego miasta, gdzieś między życiem a śmiercią.
\end{abstract}

Przet. Kordian Bobowski

Studia Filmoznawcze 38, 2017

(C) for this edition by CNS 